\title{
W literaturze polskiej odkrywają glębokq wiedzę o świecie... O studiach polskich na Columbia University
}

\author{
z Anną Frajlich rozmawia Ewa Kołodziejczyk
}

Nauczała Pani języka polskiego i literatury polskiej na uniwersytecie Columbia w Nowym Jorku od 1982 do 2016 roku. Jak znalazla się Pani na tej uczelni w roli wykladowcy?

Droga była długa i kręta. Na Uniwersytecie Warszawskim u profesor Janiny Kulczyckiej-Saloni obroniłam w 1965 roku pracę magisterską o Stanisławie Brzozowskim. Po studiach cztery lata pracowałam w redakcji czasopism dla niewidomych. Między innymi pierwsze egzemplarze słynnego w stanie wojennym „Niewidomego Spółdzielcy” wyszły spod moich rąk. Jednocześnie uczęszczałam jako wolny słuchacz na seminarium doktorskie prof. Saloniowej. Wydarzenia 1968 roku spowodowały, że w 1969 roku zdecydowaliśmy się na emigrację. Była to dramatyczna decyzja. Myślałam, że to oznacza koniec moich zawodowych możliwości. Mój szef, niewidomy pisarz Jerzy Szczygieł, twórca i redaktor naczelny „Niewidomego Spółdzielcy” napisał do przebywającego w Stanach Jana Kotta, prosząc go o poparcie dla mnie i Jan Kott zaprotegował mnie na stanowisko lektorki języka polskiego na Uniwersytecie Stanowym w Stony Brook, gdzie pracowałam jeden rok akademicki 1970-71. Praca wiązała się z kilkugodzinną podróżą, która pochłaniała większą część zarobku, niemniej jednak było to jakieś zaczepienie. Niestety po roku pojawiła się osoba, która zaproponowała, że będzie uczyła za darmo, o czym zresztą dowiedziałam się po fakcie i straciłam tę pracę. Byliśmy w bardzo ciężkiej sytuacji i ratunek przyszedł z niespodziewanej strony. Dr Wolf Szmuness, znany na świecie epidemiolog, również z naszej emigracji, przyjął mnie do pracy. Następne cztery lata spędziłam w laboratorium epidemiologicznym przy nowojorskiej stacji krwiodawstwa i to była dla mnie prawdziwa szkoła amerykańskiego życia w najlepszym tego słowa znaczeniu. W międzyczasie debiutowałam wierszami w prestiżowych londyńskich „Wiadomościach”, co otworzyło mi drogę do polskiego środowiska intelektualnego w Nowym Jorku. Spotkałam tu profesor rusycystyki Zoyę Yurieff, która skłoniła mnie do złożenia papierów na Wydział Slawistyki, na Uniwersytet Nowojorski - drugą po Columbii najbardziej prestiżową uczelnię w Nowym Jorku. Zaczęłam studia 
doktoranckie na New York University i jako wolny strzelec pisałam korespondencje o nowojorskim życiu kulturalnym do Wolnej Europy. Studia trwały dość długo, ponieważ nie miałam pieniędzy na pełną opłatę. W pewnym momencie zwolniło się miejsce lektora na Columbii i złożyłam podanie. Na pytanie kierownika katedry, czy uczyłam języka na amerykańskiej uczelni, mogłam odpowiedzieć twierdząco - wówczas przydał mi się bardzo ów lektorat w Stony Brook. W 1982 roku zaczęłam swój pierwszy lektorat na Columbii. Odmiennie niż obecnie, kiedy to doktoranci prowadzą zajęcia z literatury, wówczas bez doktoratu nie wolno było uczyć tego przedmiotu, toteż zaczęłam wykładać literaturę, obok lektoratów, dopiero kilka lat później.

Studiowała Pani rusycystykę na New York University i tam obronila Pani doktorat The Legacy of Ancient Rome in the Russian Silver Age. Jak Pani praca na Columbii wiąże się z tym doświadczeniem?

Sama praca doktorska nie wiąże się z prowadzeniem zajęć z języka i literatury polskiej. Ale właśnie studiowanie innej literatury dało mi dodatkową perspektywę. Ponadto, ponieważ wydałam też książkę, od czasu do czasu ktoś zwraca się do mnie o recenzje innych książek $\mathrm{z}$ tego zakresu i nawet do dziś na konferencjach naukowych prowadzę panele na zbliżone tematy, tj. na temat związków literatury rosyjskiej z kulturą klasyczną. Wzięłam nawet udział w międzynarodowej konferencji w Izraelu zorganizowanej w setną rocznicę wojny rosyjsko-japońskiej, jako że wiele analizowanych przeze mnie utworów wiązało się z tematem tej wojny. Ale same studia doktoranckie i doktorat jako taki stały się przede wszystkim kartą wstępu do środowiska amerykańskich slawistów, grupy szalenie interesującej pod względem intelektualnym i każdym innym. A samo doświadczenie doktoratu przydaje się bardzo w pracy dydaktycznej, w ocenianiu innych prac, w prowadzeniu konsultacji z doktorantami. Wprawdzie na Columbii nie ma doktoratu z literatury polskiej, ale wielu slawistów i historyków zalicza tzw. poboczną specjalizację z języka polskiego.

Jaki program nauczania zaproponowała Pani studentom? Jak zmieniał się on w ciągu lat?

W pierwszym rzędzie musiałam zorientować się, co jest na rynku amerykańskim, polskim, a także międzynarodowym w sensie podręczników do nauczania języka, a także jakie są przekłady, jeżeli chodzi o literaturę. Pierwszym podręcznikiem, którym posługiwałam się jeszcze w Stony Brook, był podręcznik profesora Alexandra Schenkera, ale kiedy podejmowałam pracę na Columbii, postawiono mi warunek, abym korzystała z innego podręcznika. Zaczęłam od podręcznika Marii Grali i Wandy Przywarskiej $W$ Polsce po polsku, który bardzo dobrze służył kilku rocznikom moich studentów, potem przeszłam na podręczniki profesora Władysława Miodunki, z których znów kilkanaście roczników moich studentów 
nauczyło się języka. Szczególnie podręcznik Uczmy się polskiego ze znakomitym video przysłużył się moim studentom. Musiałam wówczas wystąpić do władz uniwersytetu o kupno potężnej machiny, aby odtwarzać filmiki. Machina ta długo jeszcze, na wszelki wypadek, stała w czytelni naszego wydziału. Korzystałam też z całej serii pomocniczych materiałów w zielonych okładkach, opracowanych przez Uniwersytet Jagielloński, a także takich jak Piotra Grancarka Czas na czasownik oraz Stanisława Mędaka Liczebnik też się liczy. To już głównie jako dodatkowe ćwiczenia na zajęciach dla zaawansowanych, w których podstawą była wciąż nieoceniona antologia Alexandra Schenkera Fifteen Modern Polish Short Stories. Prowadziłam też czasem lektorat pod nazwą Professional Polish for Heritage Speakers dla studentów, którzy mówili po polsku, ale nie umieli posługiwać się językiem literackim, naukowym, profesjonalnym. W tym celu, prócz antologii Schenkera z dodatkiem Suplemental Materials Leonarda Polakiewicza, posługiwaliśmy się wyborem tekstów opracowanych przez Roberta i Halinę Rothsteinów Polish Scholarly Prose. Obecnie istnieje cały asortyment takich i innych antologii wydanych w Polsce, w Stanach Zjednoczonych i w Anglii, jest więc z czego wybierać. W Stanach szczególnie warto zwrócić uwagę na dorobek w tej dziedzinie Oscara Swana. Jeżeli chodzi o kurs dla początkujących i średniozaawansowanych wiele lat opierałam się na serii Hurra!!! Po polsku Małgorzaty Małolepszej i Anety Szymkiewicz. Co naturalnie wiąże się z tzw. metodą komunikatywną. Jak wspomniałam, przez pierwsze lata uczyłam tylko języka, jeszcze wówczas istniała na Columbii pozycja profesora wykładającego polską i rosyjską literaturę, byli to kolejno profesorowie: Harold Segel i David Goldfarb. Od początku lat 90. prowadziłam jeden wykład z literatury rocznie. W ten sposób studenci mogli zaliczyć $2-3$ pozycje z polskiej literatury. W ciągu ostatnich ośmiu lat nauczanie języka, literatury, wszelkie konsultacje weszły wyłącznie w zakres moich obowiązków. Ponieważ nasz uniwersytet jest członkiem konsorcjum, na zajęcia uczęszczają studenci z kilku innych uniwersytetów. Głównie z tzw. ligi bluszczowej, ale też paru innych uczelni nowojorskich. Kilka lat temu doktorant Uniwersytetu Yale co tydzień przyjeżdżał z New Haven, oddalonego o parę godzin drogi.

\section{Jakie metody nauczania trudnych zagadnień polszczyzny i literatury polskiej wypracowala Pani na Columbii?}

Oczywiście podręcznik, nawet najlepszy, jest tylko podstawą, czasem rusztowaniem. Studentów należy motywować, a nawet najbardziej umotywowanych - prowokować do posługiwania się nowym językiem. Najważniejsze jest zmobilizowanie studenta do wyrażania siebie w danym języku. Albo, jeżeli chodzi o literaturę, odnajdywania siebie w dziele literackim. Starałam się zawsze skłonić ich do tego. Pomagali mi w tym oni sami. Bardzo szybko zauważyłam, że moi studenci są szczerzy w wypowiadaniu swoich myśli i poglądów, bez uciekania 
się do ogólników. Po lekturze opowiadania Różewicza pt. Grzech, w którym młodociany narrator tłucze piękną wazę, zadałam studentom temat do opracowania: Najpiękniejsza rzecz w moim domu. W ciągu kilku lat zebrałam ciekawe, wzruszające w swej szczerości wypowiedzi. Tak jak były, z błędami językowymi, wysłałam je poecie. Różewicz natychmiast przesłał to do „Kwartalnika Artystycznego", gdzie ukazały się w druku. Innym razem w małej czteroosobowej grupie, przy lekturze każdego opowiadania zadawałam studentom podobne pytania do opracowania. Po kilku takich lekturach zobaczyłam, że tworzą one swoisty portret grupy. Kierownik katedry zgodził się, abyśmy zrobili z tego maleńką broszurę. Staram się zawsze, aby studenci na lektoracie mieli jak najbliższą i aktywną relację z językiem. Robią oni większe i mniejsze indywidualne projekty - filmowane wywiady autentyczne lub wymyślone. Bardzo często oni sami poddają mi jakieś pomysły. Kiedyś studentka, której brat zginął w Wietnamie, podczas rodzinnego Święta Dziękczynienia przeczytała w rodzinie Hymn o tyżce zupy Józefa Wittlina, który czytaliśmy na lektoracie. Od tamtego czasu czytałam ten wiersz ze studentami przed tym właśnie świętem. Niekiedy, aby skłonić studentów lektoratu do uważnej lektury opowiadania albo wiersza, zadawałam im ilustrowanie tekstów. To oczywiście wymaga ponownej lektury i pracy wyobraźni. Kiedyś taki rysunek na podstawie tekstu Artura Liskowackiego przesłałam autorowi i sam ze zdumieniem stwierdził, że szkic dokładnie przedstawia opisaną osobę. Doceniam metodę komunikatywną w nauczaniu języka, którą w dużej mierze stosowałam jeszcze przed tą najnowszą modą. Ale gramatyka, fonetyka fascynowały mnie od najmłodszych lat, dzielę się ze studentami swoją wiedzą. Zależy mi, aby rozumieli te procesy. Lubię też wtrącić trochę komparatystyki, powtarzam, że mniej więcej tyle samo łacińskich słów weszło do polskiego, ile do angielskiego, a reszta to kalki językowe. W ten sposób uświadamiam im, że mają zasób słów, z którego nie zdają sobie sprawy. Bardzo ważnym narzędziem jest humor, a także piosenki.

\section{Kto glównie podejmowal naukę polskiego na Pani kursach?}

Zapisanie się na kurs czy seminarium jest dla studenta poważną decyzją. Wbrew potocznym poglądom nie zapisują się ze względów sentymentalnych, bo studia są na to zbyt kosztowne, ponadto jest to ciężka praca, muszą dostać dobry stopień, aby nie obniżyć sobie ogólnej średniej. Zapisują się, ze względów merytorycznych, studenci różnych wydziałów, którzy chcą zaliczyć język polski jako obcy, a wśród studentów slawistyki ci, którzy wybierają język polski jako obowiązkowy drugi język słowiański. Wśród pozostałych są studenci historii Europy Wschodniej, historii Żydów, lingwistyki, spraw międzynarodowych i innych specjalności. Zdarzają się naturalnie Polacy lub osoby mające jakieś rodzinne związki z Polską, ale miałam Chińczyków, Japończyków, miałam kiedyś młodych mormońskich misjonarzy, którzy jeździli do Polski i po powrocie chcieli wzmocnić 
podstawy. To podaję jako ciekawostkę. Muszę zaznaczyć, że frekwencja na takim lektoracie na Columbii waha się pomiędzy liczbą 1 a 11. Polski należy do tzw. rzadziej oferowanych języków.

\section{Jak Pani studenci odbierają literaturę polską? Jakie są ich preferencje co do autorów i tematów?}

Muszę powiedzieć, że entuzjastycznie. W nauczaniu literatury w pierwszej fazie opierałam się na modelu, który znałam ze swoich lat studenckich, tj. raczej według kryteriów chronologicznych lub okresów literatury. Ale z czasem wypracowałam bardziej komparatystyczne tematy kilku wykładów i seminariów. Kilku, bo każdy taki wykład jest oferowany raz na 3-4 lata, aby studenci w ciągu czterech lat studiów, zarówno licencjackich jak i doktoranckich mieli każdego roku inną ofertę. Przeważnie jest to wykład prowadzony po angielsku i studenci dostają wybór lektury przynajmniej w dwóch językach. Wybrałam tematy, które mnie samą fascynowały, a jednocześnie dawały jakiś obraz strukturalny, jak nowela, czy też problemowy, jak powieść międzywojenna lub postzależnościowa. Oto tytuły seminariów, które mam do zaoferowania: Mickiewicz, Polish Short Story in the Comaprative Context, Best Sellers of Polish Prose, Unbound And Post-Dependent - The Polish Novel After 1989, North America in the Mirror of Polish Literature oraz polska poezja dwudziestego wieku. Prowadzę też indywidualne konsultacje ze studentami, którzy chcą w ten sposób zaliczyć literaturę polską. Jeżeli student nie ma preferencji, kieruję go w stronę Wesela Wyspiańskiego, który jest takim sezamem tematów polskiej literatury. Najczęściej studenci przychodzą ze swoją propozycją, wówczas ja mam okazję nauczyć się czegoś nowego, jak np. podczas konsultacji ze studentem, który pisał pracę doktorską o łysenkoizmie w Polsce. Albo kiedy studentka zmusiła mnie do przeczytania powieści Kraszewskiego $\dot{Z} y d$. Muszę powiedzieć, że od początku studenci zaskakują mnie swoim odczytaniem literatury polskiej. Może dlatego, że nikt im od dzieciństwa nie wbijał do głowy, że „Słowacki wielkim poetą był". Miałam studentkę (obecnie jest profesorem zwyczajnym), która postawiła i udowodniła tezę, że większość scen w Panu Tadeuszu jest wynikiem podglądania. Pewien student medycyny napisał esej Egzystencja i esencja medycyny $w$ powieściach dwudziestolecia międzywojennego, student ekonomii przeliczył wszystkie ceny występujące w pamiętnikach Niemcewicza na współczesne. Starałam się w miarę swoich możliwości, aby prace te znalazły jakiś oddźwięk. Organizowałam panele ze studentami na konferencjach slawistycznych lub Polskiego Instytutu Naukowego. Niektórzy sami starają się umieścić swoje teksty w pismach naukowych. W literaturze polskiej odkrywają, odnajdują głęboką wiedzę o świecie i życiu. Czasem mówią mi, że ich rówieśnicy w Polsce nie znają książek, które oni czytają z zapałem. 
Pani wychowankowie, absolwenci Columbii często wiążą swoje życie zawodowe z kulturą polską. Czy może Pani o nich coś więcej opowiedzieć?

Mam gdzieś listę byłych studentów, którzy są profesorami uniwersytetów w Stanach i w Europie, tłumaczami, pracownikami Departamentu Stanu. Naukowo pracują najczęściej w dziedzinie slawistyki, historii Europy i Polski, historii Żydów, są tacy, którzy wykładają w Polsce język angielski. Jest paru dziennikarzy, nawet muzykologów. Wśród tych ostatnich pianistka i muzyko$\log$ I-Chen Chen, która obroniła doktorat na Uniwersytecie Nowojorskim pisząc o balladach Szopena. Ja byłam jej konsultantem w dziedzinie Mickiewicza. Po obronie, w której brałam udział, wydała książkę Narrative in the Ballades of Fryderyk Chopin. Rhythm as a Reflection of Adam Mickewicz's Poetic Ballads. Obecnie na Columbii pisze doktorat osoba, która pracuje nad historią związków zakonów w Niemczech i Polsce u schyłku średniowiecza. Nawet ja nie rozumiem zwrotów w tej korespondencji. Podkreślam to, bo często zdarza mi się spotykać ludzi, głównie Polaków, którzy nie rozumieją, po co ktoś w Stanach, szczególnie ktoś, kto nie jest Polakiem, uczy się języka polskiego lub interesuje się balladami Mickiewicza. Kiedyś w „Gazecie Wyborczej” ukazał się wywiad z naszą byłą studentką Nancy Sinkoff, od lat profesorem Uniwersytetu w Rutgers. W 2013 roku nasz doktorant i mój były student wydał swój przekład Pięknych dwudziestoletnich Hłaski. Recenzja ukazała się nawet w „Wall Street Journal”. Jeden z naszych absolwentów, Thomas Anessi, pracuje na uniwersytecie w Polsce i ma wiele przekładów i publikacji na swoim koncie.

\section{Uczyła Pani wnuczkę Czesława Miłosza. Jak wspomina Pani spotkanie $\mathrm{z}$ nią?}

Erin Gilbert rozpoczęła studia w Barnard College, który jest z Columbią związany i mieści się po drugiej stronie Broadwayu. W krótkiej ankiecie, którą dawałam studentom do wypełnienia na pierwszej lekcji, napisała, że ma dziadka, polskiego poetę - Czesława Miłosza. Nie wiedziałam, że Erin to żeńskie imię, zadzwoniłam do Renaty Gorczyńskiej i powiedziałam, że mam wnuka Miłosza na lektoracie. Miłosz nie ma wnuka - brzmiała odpowiedź. W ten sposób dowiedziałam się, że Erin to imię żeńskie. Miłosz był bardzo szczęśliwy, że Erin uczy się polskiego i przy spotkaniach zawsze mówił o niej „Pani studentka”. Chodziła też na wykład o Miłoszu i Herbercie Harolda Segela. Parę lat temu zorganizowałam na Columbii nadzwyczaj udaną promocję książki wspomnień o Miłoszu An Invisible Rope. Portraits of Czesław Miłosz, pod redakcją Cynthii L. Haven, tam znów spotkałyśmy się z Erin. Mam dwa anegdotyczne wspomnienia dotyczące tego lektoratu. Pamiętając o związku zgody, Erin napisała kiedyś „bardzo kocham moja dziadka". Innym razem, ćwicząc niedokonane czasowniki, natknęliśmy się na wyrażenie ,wyprostowywać gwoździe”. Wdaliśmy się w dyskusję na temat postkryzysowej mentalności. A ponieważ byli to studenci w dość depresyjnych 
nastrojach, zauważyłam, że może wyprostowywanie gwoździ byłoby lepsze od terapii. Erin okazała się nadzwyczaj dzielną i ambitną osobą. Pokonała wiele trudności, ukończyła medycynę i zrobiła doktorat, wyszła za mąż, założyła rodzinę. I jest bardzo cenionym dermatologiem.

Jak usytuowałaby Pani doświadczenie pracy akademickiej we własnej karierze, drodze literackiej?

$\mathrm{Na}$ to pytanie trudno mi odpowiedzieć. Z całą pewnością przebywanie w sferze języka i literatury jakoś wpłynęło, może coś stało się jakąś inspiracją. Musiałabym przebadać. Może większy związek ma to z moimi pracami krytycznymi, esejami naukowymi, dorobkiem recenzenckim. Najważniejszą sprawą jest to, że mogłam zarabiać na życie pracą, która jest moim żywiołem.

\section{Jak ocenia Pani aktualną pozycję studiów polskich na slawistykach ame- rykańskich? \\ Sytuacja studiów polskich, a także innych języków słowiańskich, jest dość chwiejna. Zarówno liczba studentów, jak i budżet zmniejszają się z każdym ro- kiem. W Polsce nie ma poparcia dla nauczania języka i literatury. To są dziedziny uważane za mało snobistyczne. A w Stanach poparcie dla języków waha się w za- leżności od priorytetów.}

Jakiego rodzaju wsparcie, Pani zdaniem, krajowe polonistyki i instytucje popularyzujące literaturę oraz czytelnictwo mogłyby zaoferować wykładowcom i studentom polonistyk w Stanach Zjednoczonych?

Chciałabym zaznaczyć, że nasi studenci jeżdżą do Polski na letnie kursy $\mathrm{i}$ to jest bardzo ważny zastrzyk, jeżeli chodzi o ich postępy. Na Katolickim Uniwersytecie Lubelskim dostawali nawet pewną zniżkę. W Polsce nie ma dostatecznego zrozumienia wagi tego przedmiotu. Jeżeli student amerykański poświęca kilka lat na studiowanie języka i kultury polskiej, powinno się to spotkać z uznaniem, a nie z pytaniem: po co i dlaczego. Od lat staram się zachęcić specjalistów polskich do zorganizowania prestiżowych międzynarodowych konkursów dla studentów języka polskiego. Rosjanie mają takie konkursy od dziesięcioleci. Są konkursy dla uczelni z ligi bluszczowej, są bardziej popularne; obejmują one eseje po rosyjsku na różnych poziomach. Zwycięzcy otrzymują dyplomy, które mogą wpisać do swoich osiągnięć i to się liczy w dalszych studiach i karierze. Wiem, że nie jest to łatwe, ale tacy studenci są bezinteresownymi ambasadorami polskiej kultury i to należałoby doceniać, i wspierać.

Anna Frajlich-Zając - polska poetka, prozaik i wykładowca języka i literatury polskiej na Uniwersytecie Columbia w Nowym Jorku, na stałe mieszkająca w Stanach Zjednoczonych. Doktoryzowała się z literatury rosyjskiej na New York University. 
Autorka kilkunastu tomów poetyckich, Laureatka Nagrody Fundacji Kościelskich (1980), nagrody Fundacji Władysława i Nelly Turzańskich (2003), nagrody Związku Pisarzy Polskich na Obczyźnie za całokształt twórczości (2015). W 2002 roku odznaczona Krzyżem Kawalerskim Orderu Zasługi Rzeczypospolitej Polskiej, uhonorowana tytułem Ambasador Szczecina (2007) oraz Wybitnego Polaka w USA w dziedzinie kultury. Publikowała m.in. w „Tygodniku Powszechnym”, „Akcencie”, „Odrze”, „Więzi”, „Pograniczach”, „Rzeczpospolitej” „eleWatorze” i wielu innych. 